\title{
Optimal lender of last resort policy in different financial systems
}

\section{Falko Fecht}

(Deutsche Bundesbank)

Marcel Tyrell

(University of Frankfurt and Trier)

Discussion Paper

Series 1: Studies of the Economic Research Centre No 39/2004 
Editorial Board:

Heinz Herrmann

Thilo Liebig

Karl-Heinz Tödter

Deutsche Bundesbank, Wilhelm-Epstein-Strasse 14, 60431 Frankfurt am Main, Postfach 1006 02, 60006 Frankfurt am Main

Tel +49 69 9566-1

Telex within Germany 41227, telex from abroad 414431, fax +49695601071

Please address all orders in writing to: Deutsche Bundesbank,

Press and Public Relations Division, at the above address or via fax No +4969 9566-3077

Reproduction permitted only if source is stated.

ISBN 3-86558-034-3 


\section{Abstract:}

In a framework closely related to Diamond and Rajan (2001) we characterize different financial systems and analyze the welfare implications of different LOLR-policies in these financial systems. We show that in a bank-dominated financial system it is less likely that a LOLR-policy that follows the Bagehot rules is preferable. In financial systems with rather illiquid assets a discretionary individual liquidity assistance might be welfare improving, while in market-based financial systems, with rather liquid assets in the banks' balance sheets, emergency liquidity assistance provided freely to the market at a penalty rate is likely to be efficient. Thus, a "one size fits all"-approach that does not take the differences of financial systems into account is misguiding.

Keywords: Financial Crises, Lender of Last Resort, Comparing Financial Systems

JEL Classification: D52, E44, E52, E58, G21 


\section{Non technical summary}

In this paper, we take a first step to investigate which form of liquidity assistance to banks a lender of last resort should follow given the type of financial system the banks are embedded. Nowadays it is well proven fact that even with regard to industrialized countries financial systems differ in many dimensions. As a consequence, a classification of financial systems in market-based or bank-based financial system emerged. However, we focus our analysis on one aspect, namely the importance of relationship lending in market-oriented and bank-dominated financial systems. Our starting point is that strong relations between firms and banks are more predominant in bank-based financial systems.

First, we develop a taxonomy of crises situations, namely slight, moderate or severe liquidity crises, whereas the occurrence of a certain crisis situation depends on the magnitude of the negative macroeconomic shock that causes an aggregate liquidity shortage. In addition, we argue that the importance of relationship lending has an influence on the occurrence of crises situations as well. Market-based financial systems end up more often in light and severe liquidity crises while in bank-based financial systems moderate liquidity crises are more likely. The higher marketability of loans in market-based systems on the one hand is more efficient in buffering small aggregate shocks, but on the other hand it gives stronger incentives to investors to liquidate their stakes in the banks in case of a big shock.

In the second part we analyze the welfare implications of different lender of last resort-policies in these crises situations. We consider two alternatives, i.e. discretionary individual liquidity assistance to illiquid banks and market interventions provided along the rules of Bagehot. In comparing both policies, it can be shown that the relative welfare gains of individual liquidity assistance are higher particularly in moderate liquidity crises. Providing assistance by market interventions leads to a waste of liquidity since part of it ends up in liquid banks. This waste of liquidity is the more severe the more illiquid bank loans are. However, individual liquidity assistance is associated with more cost intense information requirements. Taking higher information costs of an individual liquidity assistance into account, we come to the conclusion that individual liquidity assistance may be preferable in bank-dominated financial systems but not in market-oriented financial systems where market interventions might be more appropriate. Of course, there are some qualification to this conclusion. Most important, our model is quiet about possible moral hazard behavior of banks induced by the lender of last resort-policy. This aspect will be analyzed in future research. 


\section{Nicht technische Zusammenfassung}

Im Rahmen einer modelltheoretischen Analyse gehen wir der Frage nach, inwieweit es notwendig ist, die Ausgestaltung der nationalen Lender of Last Resort-Politik an dem in einem Land vorherrschenden Finanzsystemtypus auszurichten. Ausgangspunkt unserer Analyse ist die inzwischen wissenschaftlich etablierte These, dass sich die Strukturen der Finanzsysteme industrialisierter Länder stark voneinander unterscheiden, wobei sich eine Klassifikation in bankdominierte oder kapitalmarktorientierte Finanzsysteme durchgesetzt hat. Diese Unterscheidung bilden wir in unserem Modellrahmen in der Weise ab, dass Hausbankbeziehungen eine je nach Finanzsystemtyp unterschiedlich große Bedeutung zukommt: Bankdominierte Finanzsysteme sind stärker durch diese Art der Finanzierungsbeziehung geprägt als kapitalmarktorientierte Systeme.

Zunächst charakterisieren wir unterschiedliche Typen von Finanzkrisen (schwere, moderate und leichte), die je nach Ausmaß des makroökonomischen Liquiditätsschocks auftreten. Sie unterscheiden sich darin, inwieweit aufgrund des Liquiditätsengpasses Finanzierungsbeziehungen vorzeitig abgebrochen werden und/oder es zu Bankenzusammenbrüchen kommt. Wir zeigen auf, dass es in durch enge Hausbankbeziehungen gekennzeichneten Finanzsystemen häufiger zu moderaten Liquiditätskrisen kommt, während in kapitalmarktorientierten Finanzsystemen Schocks eher in schwache oder starke Liquiditätskrisen münden. Die höhere Marktfähigkeit der vergebenen Kredite in kapitalmarktorientierten Finanzsystemen kann kleinere makroökonomische Schocks zwar besser abpuffern, führt jedoch bei großen Schocks zu einer höheren Krisenanfälligkeit der Banken, da Anleger einen stärkeren Liquidationsanreiz haben.

Im zweiten Schritt untersuchen wir dann, welche Form der Liquiditätsbereitstellung durch eine Zentralbank in den jeweiligen Krisenszenarien effizienter ist. Wir zeigen, dass insbesondere in moderaten Krisen eine individuelle Liquiditätsbereitstellung an illiquide Banken vorzuziehen ist. Der Grund hierfür liegt darin, dass eine Marktintervention keine zielgenaue Liquiditätsbereitstellung an illiquide Banken erlaubt. Sie bringt eine "ineffiziente Liquiditätsverschwendung" mit sich, die umso größer ist, je illiquider Bankkredite sind. Allerdings geht die individuelle Unterstützung mit höheren Informationserfordernissen für die Zentralbank einher. Bei nicht zu hohen Informationskosten kommen wir somit zu dem Gesamtergebnis, dass in bankdominierten Finanzsystemen eine Lender of Last Resort-Politik im Sinne einer individuellen Liquiditätsbereitstellung eher angebracht ist, während in kapitalmarktorientierten Finanzsystemen eine Marktintervention entlang der Regeln von Bagehot vorzuziehen ist. Unsere Ergebnisse berücksichtigen dabei allerdings nicht, in welcher Weise die unter- 
schiedlichen Formen der Liquiditätsbereitstellung moral hazard auf Seiten der Banken hervorrufen. Diesen Aspekt wollen wir in einem weiteren Forschungsprojekt integrieren. 


\section{Contents}

1 Introduction 1

2 The framework 3

2.1 The setup . . . . . . . . . . . . . . . . . . . 3

2.2 Financial structure of firms and banks . . . . . . . . . . . . . 6

2.3 Local lending markets and the time structure of the model . . . . . . . 9

3 Stability of an individual bank $\quad 11$

4 Equilibrium in the liquidity market $\quad 12$

5 Optimal LOLR-policy $\quad 19$

6 Conclusions $\quad 26$ 


\section{List of Figures}

1 Equilibrium in a slight liquidity crisis . . . . . . . . . . . . . 15

2 Equilibrium in a moderate liquidity crisis . . . . . . . . . . . . 16

3 Equilibrium in a severe liquidity crisis . . . . . . . . . . . . . . . . . 17 


\section{Optimal Lender of Last Resort Policy in Different Financial Systems*}

\section{Introduction}

In the last two decades financial crises, a phenomenon that most observers in the 1970's thought to be a relict of the past, has reawakened the interest of academics and practitioners. Following the collapse of the Bretton Woods agreement in 1973 and the subsequent wave of deregulation in many countries, financial crises reemerged. For instance, Lindgren and Saal (1996) found that about three quarter of the IMF's member countries suffered some form of banking crises, though panics in the traditional sense were avoided either by central bank interventions or by explicit or implicit government guarantees. The experience with crises in Scandinavian countries like Norway, Finland and Sweden in the 1980's and more recently in East-Asian and Latin-American countries shows that crises were particularly disruptive in terms of the depth of ensuing recessions. This explains why the question of how to prevent or handle financial crises is one of the most lively debated policy and research issues in the financial community.

In this debate, largely unanimity prevails that the maintenance of financial stability is facilitated by well-designed "safety net" arrangements aimed at both limiting the risk of disruption in the financial system (crisis prevention) and the consequences of disruption if it arises (crisis management). A central element of these arrangements is the lender of last resort. There is considerable agreement on the need of a lender of last resort to provide emergency liquidity assistance in reaction to an adverse shock which causes an abnormal increase in demand for liquidity that cannot be met from an alternative source. Usually this role of a lender of last resort (LOLR) is assigned to the central bank. ${ }^{1}$

${ }^{*}$ We would like to thank Jean-Charles Rochet, Elena Carletti, and the participants of the CFS Summer School 2002, of the conference on "Banking, Financial Stability and the Business Cycle" at the Sveriges Riksbank 2004, of the seminar at the Federal Reserve Bank of Kansas City 2004, of the seminar at the Deutsche Bundesbank 2004, and of the European Economic Association Meeting in Madrid 2004 for stimulating discussions and very helpful comments. The views expressed herein are those of the authors and not those of the Deutsche Bundesbank.

${ }^{1}$ See for a discussion of the lender of last resort function(s) Freixas, X. et al. (November 1999). We do not want to touch the issue if there should (and could) be an institutional separation between a central bank which is responsible for the conduct of monetary policy and a lender of last resort; on this topic see Goodhart (1995). Also we do not analyze the potential agency conflicts between deposit insurance fund, central bank and bank supervisors; on this see Repullo (2000) and Kahn and Santos (2001). 
However, the question arises what are the principles that a lender of last resort is supposed to follow. As far back as 1873, Bagehot (1873), based on the work by Thornton (1802), formulated rules of a lender of last resort policy. He suggested that in a crisis, the lender of last resort should lend freely, at a penalty rate, on the basis of collateral that is marketable in the ordinary cause of business when there is no panic. ${ }^{2}$ Especially, to discourage risk taking by individual institutions the view holds that the lender of last resort should lend whenever possible only to the market at penalty rate and only against good collateral. By this maxim the doctrine of what a lender of last resort should do today is still well-captured besides coming under some criticism by authors like Goodhart (1999) or Giannini (1999). ${ }^{3}$

In this paper, we take a first step to investigate if such a "one size fits all"-approach with respect to lender of last resort policy makes much sense having in mind the differences between financial systems of various countries. This issue while very important is highly complex because as the literature on comparative financial systems shows, there are many dimensions in which financial systems differ. ${ }^{4}$ However, we focus our very simple analysis on one dimension, namely the differences in the importance of relationship banking in market-oriented and bank-dominated financial systems. Our research question is the following: Given that financial structures differ in this aspect across countries, shouldn't also the lender of last resort policies with respect to the form of liquidity assistance to the financial system be different?

More specifically, we build our analysis on the Diamond/Rajan-framework and use this modelling structure as our starting point to incorporate certain stylized facts on differences between bank- and market-based financial systems. ${ }^{5}$ The approach will be extended to explore what happens to the functioning of a financial system if there is an aggregate shortage of liquidity - if the supply of liquid assets is small relative to aggregate liquidity demand. We are able to define different cases for the resulting equilibrium on the market for liquidity and thus develop a taxonomy of crises situations. This gives us some hints on the probabilities and welfare consequences of certain crises situations in the respective financial systems. In turn this allows us to give a first assessment of the type of interventions a lender of last resort should follow. Especially,

\footnotetext{
${ }^{2}$ See for instance Fischer (1999), Giannini (1999) and Goodhart (1999) for a discussion of these rules.

${ }^{3}$ See for instance Fischer (1999).

${ }^{4}$ See Allen and Gale (2001) for a recent survey. This literature includes theoretical analysis, e.g. Allen and Gale (2000), as well as more empirically oriented work such as Franks and Mayer (1995) and Hackethal, Schmidt, and Tyrell (2002)

${ }^{5}$ See Diamond and Rajan (2001) for the basic framework and Diamond and Rajan (2002) for an application to banking crises.
} 
the question when - if at all - the lender of last resort should charge a penalty interest rate and if the lender of last resort should lend only to the market or to individual institutions, will be analyzed with regard to the different financial systems. Our main result is that under reasonable assumptions individual liquidity assistance to banks is preferable in bank-dominated financial system while in market-oriented systems a policy following Bagehot's rules should be pursued.

Of course, we are not the first who discuss optimal lender of last resort policy and especially the classical market doctrine of the lender of last resort. ${ }^{6}$ But to our knowledge we are the first who analyze in a theoretical framework the interrelationship between characteristic differences of financial system configurations and adequate lender of last resort policies.

The remainder of the paper is organized as follows. Section 2 presents our framework. In section 3 the stability of an individual bank will be investigated. It follows an analysis of the equilibrium in the liquidity market in section 4 . In section 5 we describe the optimal lender of last resort policy. Section 6 concludes.

\section{The framework}

\subsection{The setup}

Following Diamond and Rajan (2001) we consider an economy with three dates $(t=$ $0,1,2)$ and a large number of entrepreneurs, bankers and investors. Entrepreneurs are wealthless, however each of them has a project at his disposal which requires an investment $I=1$ at $t=0$. Each investor is endowed with a small amount of consumption good in comparison to the required investment size, hence we need many investors to fund a project. In addition, we assume that the aggregate endowment of all investors in the economy is lower than the total investment possibilities. Because of this shortage of investment capital at date 0 entrepreneurs and bankers must offer an expected return as high as possible to attract funding. Entrepreneurs, investors and bankers, whose role will be clarified below, are risk-neutral but differ in their preferences: Investors and bankers have a strong preference for consumption at date 1 , i.e. they have a very high discount rate $\rho$ for consumption at date 2 , whereas entrepreneurs value consumption at each date equally. Investors can storage their

\footnotetext{
${ }^{6}$ See for instance Rochet and Vives (2002) for a very interesting model that shows how a lender of last resort can avoid inefficient liquidation of banks. Freixas, Parigi, and Rochet (forthcoming) discuss how the optimal LOLR policy is affected by moral hazard problems on side of the banks.
} 
initial endowment earning a return of 1 for every unit invested, or they can invest it in the project.

Financing the projects includes some difficulties which have to be overcome. Entrepreneurs have specific abilities vis-a-vis their projects, i.e. the cash flow each entrepreneur can generate from his project exceed what anyone else can get out of it. But entrepreneurs cannot commit their human capital to the project, except on a spot basis. From this it follows that a lender can extract future repayment only by threatening to take away the project from the initial entrepreneur. The project returns $C$ generated by the initial entrepreneur are uncertain in terms of their time structure. The project pays out $C$ either at $t_{1}$ if the project produces early or at $t_{2}$ if the project is delayed. All uncertainty about projects is resolved at date 1 .

We consider two alternatives when taking away the project from an entrepreneur. The project can be restructured at any time until date 1 which will yield a payoff $c_{1}$ immediately and nothing at date 2 , or the entrepreneur can be replaced with assets redeployed to their next-best use, which does not change the timing of the produced cash flow but the level to $\gamma C$ with $\gamma<1$. Both alternatives result in a loss of surplus, since

$$
c_{1}<1<\gamma C<C
$$

However, the big difference between this two alternative is the following: The second alternative (replacement) can only be implemented by a bank who was the only initial financier of the project while restructuring can be done by any investor, irrespective of having been an initial financier of the project or not.

How can we interpret these alternatives? Restructuring is an activity which can be understood as changing the original content of the projects so that some immediate cash can be produced without any specific knowledge. One may think of this strategy as abandoning the uncertain technology and using instead a commonly known technology that produces goods quickly or stopping half-finished projects and salvaging the production goods. All investors can realize this cash flow, hence $c_{1}$ is the secondary market value of a project. On the other hand, replacing the entrepreneur and redeploying the assets to their next-best use, which yields $\gamma C$ is an activity which demands specific skills for replacing the entrepreneur but preserving the original content of the project. It may involve searching for a new entrepreneur who has similar skills to the original one, or abandoning only such aspects of the project that were particulary dependent on the old entrepreneur. Because this implies learning all about the project it takes time, effort and a constant close contact to retain this skills. Therefore, we assume that just one initial financier, effectively a "relationship lender" or banker who 
collect the savings of the investors, will undertake this costly activity. Accordingly, only the banker knows the next-best use of the project's assets. To sum up, the bank can realize $\gamma \cdot C$ from the project, if it takes the project away from the initial entrepreneur, while other investors can only realize $c_{1}$. Therefore, the initial entrepreneur will offer to repay $\gamma \cdot C$ to a bank and only $c_{1}$ to other investors.

How can we grasp the differences between financial systems in this modelling structure? One obvious difficulty lies in the fact that this framework taken at face value allows only banks to exist as intermediaries. Capital markets in the literal sense as institutions, where firms issue stocks and bonds, households buy and trade these securities and the resulting prices incorporate valuable information, are not caught in our modelling structure. Yet what makes the framework attractive is the possibility to grasp certain consequences of market-based and bank-based financial systems.

We view a bank-based system as a configuration with a relatively high $\gamma$ and a low $c_{1}$ while the reverse, a relatively low $\gamma$ and a high $c_{1}$ is true in a market-based system. A high $\gamma$ points out that usually in a bank-based system the intermediary has a great deal of information about her borrowers and their projects because of a long lasting and close relationship. As a consequence, she can enforce higher repayments from a borrower than a typical lender in a market-based system who does not collect as much knowledge and information. So the banker in a bank-based system can "replace" the entrepreneur easier, thereby retaining much of the original strategy of the initial entrepreneur. This gives her bargaining power. In our opinion, this is an essential characteristic of a bank with typically firm-specific knowledge.

On the other hand, $c_{1}$ is the payoff of restructuring. Because this restructuring is the best alternative, publicly available use, it can be interpreted as the market value of these projects. A relatively high $c_{1}$ indicates that much information about the best alternative use is released in the market. In sum, we conclude that the difference between $\gamma C$ and $c_{1}$ is rather small in market-based systems. ${ }^{7}$ The assets are relatively liquid because a great deal of information gets "externalized" through the market activities. This reflects the notion that there are many analysts working for mutual funds, pension funds and other intermediaries who gather private information and incorporate these through their trading activities in market prices which is the general advantage of a market-based system.

In bank-based systems assets are more illiquid. In countries with bank-based systems, relatively few companies are listed and accounting disclosure requirements are

\footnotetext{
${ }^{7}$ Of course, we maintain the relation $\gamma C>1>c_{1}$ for a market-based system. Only the difference is small.
} 
limited, so very little information is incorporated into stock prices. Also the number of analysts who follow stocks is small, so only limited private information is incorporated into stock prices. However, intermediaries have more information available in these systems. The greater prevalence of long term relationships, i.e. the "hausbank"relationship, in bank-based systems means that the banks are able to acquire considerable information about the firm they lend to. Typically this information will not be released to the market; instead the information will be used internally to allow a smooth functioning of the long term financial relationship and allocate resources efficiently. ${ }^{8}$ Therefore information in a bank-based system is more or less " internalized", outsiders to the financial relationship have only a small chance to get valuable information. ${ }^{9}$ Banks have strong incentives to acquire and use information because they can profit from information which doesn't leak to outsiders. However, this creates the problem that most of the assets are rather illiquid because only the banker has the relevant information. This means $c_{1}$ is small and the difference between $\gamma C$, the payment a bank can extract, and $c_{1}$, the market value of a loan, is large.

We feel that this parametrization captures one of the most important underlying causes of the observable differences between bank-based and market-based systems, namely the different ways of acquiring and using information in the respective systems.

\subsection{Financial structure of firms and banks}

What complicates the financial relations in this economy is the presence of specific skills at two different layers. First of all, original entrepreneurs with their specific abilities can generate a higher expected return from the projects than everyone else but they cannot commit this human capital on a long term basis to the projects. Thus, projects are illiquid in the sense that they cannot be financed to the full extent of their cash flows. The second layer causes the illiquidity of the loans. Only an initial lender has specific skills to extract high repayments from the entrepreneur but she also cannot commit her human capital to the loan. For these reasons the financial contracts we consider specify only who owns the physical assets conditional on the payments made. ${ }^{10}$

\footnotetext{
${ }^{8}$ See for instance Rajan (1992) and Gorton and Kahn (1992) for theoretical analysis and Elsas and Krahnen (1998) and Berlin and Mester (1998) for empirical analysis.

${ }^{9}$ See Tyrell (2003) for a discussion how these two perspectives on information, i.e. externalization and internalization, can be mapped into two approaches to the role of information in financial systems, namely the rational expectations literature on the role of prices in resource allocation and the intermediation literature which is concerned with the role of banks as delegated monitors.

${ }^{10} \mathrm{We}$ assume a court system, which can enforce financial contracts and transfer assets to lenders when contracted repayments are defaulted upon, but cannot compel entrepreneurs or bankers to
} 
Let us turn to the resulting financial structure of a firm first.

Initially the entrepreneur owns the machinery or project to produce goods. Since he has no endowment, he needs to borrow to invest and is obliged to pay back the credit later on. Hence, the contract signed by the entrepreneur specifies a repayment and the assets the financier gets in case of default. Because of his specific abilities and the limited commitment of human capital, an entrepreneur can credibly threat to withhold his human capital at any time until the cash flows are produced. That gives him bargaining power vis-a-vis the banker. Thus notwithstanding any ex-ante agreement between entrepreneur and banker, the most the banker can get as repayment for the credit is just her best outside option "replacement", which yields $\gamma C$. Only by threatening to take away the project and redeploy it to this next-best use, the banker as an initial financier can extract this amount as future repayment for the credit. In turn, this is also the maximum amount the entrepreneur can credibly pledge to an initial financier. Since the economy is short of investment capital at date 0, entrepreneurs are competing for the scarce resources and only a few of them get a loan by bidding the maximum amount they can credibly pay back. This means that in the financial contract the borrower promise to pay the banker $P_{t}=\gamma C$ on demand. If, however, the project turns out to be late and the entrepreneur cannot repay this amount and defaults, the bank has the property rights over the project's assets and will decide what to do with them next.

How can the banker refinance the project? Only the banker as an initial lender knows the next best use of the project's assets. During the course of lending she acquired specific skills which she can use to collect more on the loan than other lenders could do. Similar to an entrepreneur the banker possesses human capital that she can threaten to hold back unless investors reduce the required payment. Thus, she cannot commit to repaying to outside investors the full amount that she can extract from an entrepreneur. This also implies that the banker may not be able to raise the full present value of the loan held. But bankers themselves have no endowment, so they have to find a way to refinance the loan through outside investors, otherwise they cannot persuade investors to entrust them with their goods in $t=0$. As a consequence, the bank couldn't act as the only initial financier of an entrepreneur and the projects wouldn't be financed. ${ }^{11}$

contribute their human capital. Thus the court can help to seize the project's assets or the bank's loans, respectively. However, the value of these assets depends on the cash flow the lenders can generate out of the assets.

${ }^{11}$ Acquiring the specific collection skills to enforce repayment on the part of an entrepreneur is a costly activity which is not worth doing by a small investor in analogy to arguments given in Diamond 
As Diamond and Rajan (2001) show the bank can use a device to commit to repayment up to the full value of the loan. The bank should refinance lending by issuing uninsured demand deposits subject to a sequential service constraint. The sequential service constraint creates a collective action problem among depositors: If the bank makes an attempt to renegotiate deposit repayments she will cause a run. Rather than making concessions which may be in their collective interest, depositors find it in their individual interest to run immediately to capture full repayment of their deposits. Because of the "first come, first served" aspect of uninsured demand deposits, they cannot be negotiated down. Individually each depositor has an incentive to withdraw his claims as fast as possible because his payoff depends on his place in line. Thus withdrawing is a Nash equilibrium. In case of a run depositors seize the assets and restructure all the projects destroying any potential rent of the banker. It is not in the interest of a bank to renegotiate down an ex-ante agreed repayment because courts would enforce depositors' demands, and the rents of the banker would be destroyed. Therefore, the bank's ability to create liquidity is inseparable from its potential fragility. ${ }^{12}$ Hence in a world without uncertainty, a bank refinances entirely with demand deposits to maximizes the credit it can offer to entrepreneurs. The possibility of runs exerts market discipline on banks, although bank runs are never observed in equilibrium. Since the banker can threat not to deploy her specific collection skills on behalf of the investors at any point after the deposit is made, deposits must be demandable at any time to provide commitment value, even if consumption occurs only at date 1 or 2 .

But a bank's capital structure typically involves (long-term) capital in addition to demand deposits. The reason is that capital represents a softer claim than demand deposits, i.e. a claim that can be renegotiated. In a world of uncertain project cash flows, financing with only demand deposits carries a cost. It impose the banks to destructive runs if they truly cannot pay because the realized project cash flows of entrepreneurs are too low. In this way, Diamond and Rajan (2000) show that with observable but not verifiable uncertainty in project returns, it may be optimal for a bank to partially finance with a softer claim called capital. Capital holders cannot commit not to renegotiate because they are not subject to a collective action problem. Thus capital acts as a buffer because its value adjusts to the underlying asset values and can prevent inefficient runs. On the other hand, this allows a banker to capture some rents in the future and therefore reduces its ability to raise funds and creates liquidity in the present. The optimal capital structure of a bank has to trade-off these

(1984)

${ }^{12}$ See Diamond and Rajan (2001) for a full analysis of this mechanism. 
costs against the benefits of capital.

In the following we assume that banks face a capital requirement $k$, stating that a fraction $k$ of the present value of a bank's assets has to be refinanced using capital. ${ }^{13}$ By normalizing our financing problem and the capital structure of the bank on one investment project, we know that the bank assets are worth $\gamma C$ when the entrepreneur can repay at date 1: Owing to the capital shortage at date 0 , the bank extracts all the rent from the entrepreneur that can be pledged, leaving the entrepreneur a rent of $(1-\gamma) C$. If $D$ denotes the repayments on deposits, then $\gamma C-D$ is the surplus that can be split between the banker and the capital holder in the renegotiation process. Assuming equal division of the surplus, capital owners will be paid $\frac{1}{2}(\gamma C-D)$ and the same amount will be absorbed by the banker as a rent. It follows that $D+$ $\frac{1}{2}(\gamma C-D)=\frac{1}{2}(\gamma C+D)$ will be passed on as total pledgable payment per loan to depositors and investors holding a capital claim. Inserting this into the definition of the capital requirement $\left(k=\frac{\frac{1}{2}(\gamma C-D)}{\frac{1}{2}(\gamma C+D)}\right)$ gives the maximum amount refinanced by deposits: $D=\frac{1-k}{1+k} \gamma C$. Hence, the banker gets a rent of $\frac{k}{1+k} \gamma C$ per finished project and capital owners get the same. Thus, the total value that can be pledged to outsiders amounts to $\frac{\gamma C}{1+k}$.

\subsection{Local lending markets and the time structure of the model}

We argued in the last section that a banker acquires specific collection skills vis-a-vis entrepreneurs through her lending activity. But typically this experience or knowledge, which is costly to develop, can only be acquired for a subset of the date 0 project opportunities. For instance, a bank may only have experience in specific industries or possess knowledge about specific locations. From this it follows that each bank has a local monopoly in lending.

To simplify our analysis we assume that the economy is divided into two regions of the same size. The two regions are ex ante at date 0 identical in every respect but can become heterogenous at date 1 in the sense that the fraction of early projects in the two regions differ. More specifically, ex ante the regions are populated by many identical banks, each of them being a monopolist in their local market and facing an identical pool of (many) entrepreneurs. With probability $p_{1}$ no macroeconomic shock occurs which means that all projects in both regions generate cash flows in $t=1$. With probability $1-p_{1}$ a negative macroeconomic shock occurs which delays some projects. In one region only a fraction $\underline{\alpha}$ of the bank loans generates cash flows at date

\footnotetext{
${ }^{13}$ This requirement is either exogenously imposed by regulators or endogenously determined as a result of - in our case unmodelled - uncertainty along the line of Diamond and Rajan (2000).
} 
1 while in the other region a fraction $\bar{\alpha}$ of projects financed by banks produce early cash flows with $\bar{\alpha}>\underline{\alpha}$. Ex ante nobody knows which region will be hit by the more severe macroeconomic shock. Thus, while banks are identical ex ante, in $t_{1}$ half of them turn out to be weak, i.e. having a higher fraction of delayed projects, while the other half turns out to be strong, which means having a high fraction of projects that generate an early return.

Closing this section, let us describe the time structure of the model. At date 0 the ex ante identical banks compete for the investors' endowments. They issue a mix of deposits and capital to investors and promise them the maximum pledgable amount since consumption goods are short relative to projects at that date. Investors will invest as long as their opportunity rate of return, i.e. storage, is met. After raising cash, banks lend to entrepreneurs in their local lending market. We normalize without loss of generality the amount each bank can raise at date 0 to be 1 . In lending to entrepreneurs the banks will charge the maximum repayment $\gamma C$ on demand.

Shortly before date 1 entrepreneurs learn if their projects are early or late. In case the project is late, an entrepreneur informs his bank about the delay. Thus, banks know before date 1 the fraction of their bank loans that turns out to be early projects. As soon as a bank discovers that even with restructuring late projects it cannot generate enough liquidity to payoff depositors, the banker tries to renegotiate the deposit repayments. This will trigger right away a run and all the late projects will be restructured to yield $c_{1}$ immediately.

If their bank survives, entrepreneurs with early projects will repay $\gamma C$ at date 1. These entrepreneurs have $(1-\gamma) C$ at their disposal which they can either invest on the liquidity market or consume. Entrepreneurs with late projects will default. Then the bank decides how to deal with late projects. It can restructure the projects if liquidity is needed at date 1 or it can reschedule the loan payment until date 2 and keep the project as a going concern. Of course, what decision gives the bank a greater value depends on the prevailing interest rate and its need for funds. A market for liquidity is open at date 1 to equate supply and demand. The bank itself uses repayments from the early entrepreneurs, from the restructured late projects, and the cash invested by early entrepreneurs through the liquidity market in the bank (as deposits and capital) to repay investors at date 1 .

At date 2, the bank gets repayments from the unrestructured late projects. Entrepreneurs will consume. 


\section{Stability of an individual bank}

In this section we want to analyze the stability of an individual bank. It is important to understand how decisions in the bank will be taken because of their influence on the stability and the payoffs of the three stakeholder groups of the bank: bankers, capital owners, and depositors. The optimal decision concerning restructuring or continuing late projects depends on the particular interest rate $r$ that occurs in date $t=1 .^{14}$ Although the bank manager would always prefer to continue late projects, since only when continuing he earns a rent but gets nothing in case of restructuring, the capital owners will force the banker to maximize the net present value of the projects. ${ }^{15}$ The capital owners of the bank want to consume at date 1 and therefore they try to maximize the $t_{1}$-consumption goods available to the bank. This means they will force the banker to restructure a project if $c_{1}>\frac{\gamma C}{(1+k) r}$ and let she continue it otherwise, i.e. if $c_{1} \leq \frac{\gamma C}{(1+k) r}$. We will denote this hurdle rate with $\tilde{r}=\frac{\gamma C}{(1+k) c_{1}}$. The higher the interest rate for getting liquidity, the more valuable is restructuring because it generates liquidity immediately. But this restructuring decision is biased, because only part of late projects' return is pledgable to outside financiers of the bank. As long as $c_{1}<\frac{\gamma C}{(1+k) r}+\frac{k \gamma C}{(1+k) \rho}+(1-\gamma) C$, it is socially inefficient to restructure late projects.

Turning to the decision of depositors, we already mentioned that it is individually rational for them to withdraw their funds whenever the net present value of the bank at date 1 is not enough to fulfill their claims. Consequently, a run on the particular bank is triggered whenever the sum of deposits exceeds the net present value of the bank at date $1: D \geq V_{1} \cdot{ }^{16}$

Therefore, given that capital owners force bankers to restructure late projects be-

\footnotetext{
${ }^{14}$ In the following analysis we have taken the banks' date 0 portfolio decision concerning investment in storage and lending as given and analyze the case where the bank will not store but invest any funds in lending activity. We are sure this is the optimal decision when the probability $p_{1}$ for the state where all the projects in both regions are early, is sufficiently high.

${ }^{15}$ We will use the terms banker and bank manager synonymously. The banker will continue the project despite having a strong preference for date 1 consumption. This means that even with a high discount rate of date 2 consumption the present value of the rent she can earn is positive.

${ }^{16}$ Clearly, as in Diamond/Dybvig there exist two pure strategy equilibria in those cases where $D<V_{1}$ but $D>c_{1}$. Under these circumstances the individually rational decision of every depositor depend on his belief about the decision of all other depositors. As long as he expects the others to withdraw he also has an incentive to do so. But if he thinks the others will wait until $t=1$ he is also inclined to withdraw not before $t=1$. Here we assume that depositors will always wait until $t=1$ as long as $D \leq V_{1}$.
} 
cause $r>\frac{\gamma C}{(1+k) c_{1}}$, depositors will run if

$$
V_{1}=\alpha \gamma C+(1-\alpha) c_{1}<D=\frac{1-k}{1+k} \gamma C
$$

Solving for $(1-\alpha)$ gives the critical level of late projects that triggers a run:

$$
1-\alpha>\frac{2 k}{1+k} \frac{\gamma C}{\gamma C-c_{1}}
$$

However, if late projects are continued because $r \leq \frac{\gamma C_{1}}{(1+k) c_{1}}$ depositors will run if

$$
V_{1}=\alpha \gamma C+(1-\alpha) \frac{\gamma C}{(1+k) r}<D=\frac{1-k}{1+k} \gamma C
$$

Thus, given that capital owner want to continue late projects a run will occur if the interest rate increases beyond:

$$
r=\frac{1}{1-k \frac{1+\alpha}{1-\alpha}}
$$

It is easy to see that this interest rate level increases with $\alpha$ and $k$. A higher fraction of early projects just like a higher capital ratio increases the stability of a bank. In the following analysis we assume that the fraction of early projects in the strong region is high enough that the liquidity inflow from early projects is sufficient to repay deposits. Thus, strong banks (those with the higher fraction of early projects) never depend on the liquidity raised at the $t_{1}$-financial market to prevent a run. Therefore a run on these banks can never be triggered by interest rate increases. However, weak banks we assume to be dependent on the liquidity inflow from financial market transactions to repay depositors. Following equation (3) this means that we restrict our parameter space to

$$
\bar{\alpha}>\frac{1-k}{1+k}>\underline{\alpha} .
$$

Accordingly, we define $\hat{r}=\frac{1}{1-k \frac{1+\underline{\alpha}}{1-\underline{\alpha}}}$ and $\hat{\hat{r}}=\frac{1}{1-k \frac{1+\bar{\alpha}}{1-\bar{\alpha}}}$ as the critical interest rate level which determine the capital owners' decision on restructuring vs. continuing late projects in weak respectively strong banks.

\section{Equilibrium in the liquidity market}

The gross liquidity produced in the economy is the return on early projects. But part of the liquidity goes to banks, which split it into rents to the banker, return to capital owners and repayment to depositors. Since we assume that bank managers, capital owners as well as depositors have a discount rate of $t_{2^{-}}$consumption that exceeds 
any upper bound of the equilibrium interest rate, they will immediately consume this fraction of the liquidity. The other part of the liquidity produced by early projects are the rents of the entrepreneurs. Since they do not discount future consumption, they will supply their liquidity at the $t_{1}$-financial market, as long as they get at least a return of 1 . Given the overall fraction $(\bar{\alpha}+\underline{\alpha})$ of early projects in both regions, the aggregate liquidity supply amounts to:

$$
L^{S}=(\bar{\alpha}+\underline{\alpha})(1-\gamma) C
$$

Because all the stake holders in the bank - bank manager, capital owner and depositors - have a strong preference for immediate consumption in $t_{1}$, the bank manager will try to raise liquidity against the pledgable income of late projects, in order to repay deposits, pay the return on capital and consume his own rents.

Proposition 1 In the secondary financial market banks try to borrow liquidity from early entrepreneurs against the pledgable return of late projects.

In competing for the fixed liquidity supply of early entrepreneurs banks bid up the interest rate. An increase in the interest rate reduces the present value of the future pledgable income and the liquidity that each bank can raise.

For an interest rate that only sightly exceeds 1 this simply reduces the rents of the bank managers and the return of bank capital owners. As long as the interest rate does not increase beyond the threshold level $\hat{r}=\frac{1}{1-k \frac{1+\underline{\alpha}}{1-\underline{\alpha}}}$ banks in both regions are stable and will raise new funds against the pledgable return of their late projects from early entrepreneurs in the given mixture of capital and deposits. The demand for liquidity is given by the pledgable return of both type of banks' late projects discounted with the respective interest rate: $(2-\bar{\alpha}-\underline{\alpha}) \frac{\gamma \cdot C}{(1+k) \cdot r}$.

But for interest rates above $\hat{r}$ the liquidity available to weaker banks falls short of the liquidity needed to repay all depositors. Banks with the higher fraction of late projects will be subject to a run of its depositors. The depositors will seize the banks' late projects and restructure them. Therefore, beyond an interest rate of $\hat{r}$ weak banks will not demand any liquidity at the financial market. In contrast, the stronger banks can still raise enough liquidity to repay their depositors. Since the fraction of late projects is smaller at these bank, the fraction of liquidity provided by inflows from selling assets in the $t_{1}$-financial market is smaller and the liquidity available to these bank is less dependant on the interest rate. Therefore, at interest rates above the threshold level $\hat{r}$ only the strong banks demand liquidity against the future pledgable return of their late projects. 
However, at an interest rate exceeding $\tilde{r}=\frac{\gamma \cdot C}{(1+k) \cdot c_{1}}$ even strong banks get into trouble. But not due to a run of their depositors. The liquidity available to these banks is even at this threshold level enough to repay the deposits. ${ }^{17}$ At an interest rate above $\tilde{r}$ the returns to capital owners are higher if projects are restructured in order to generate early returns. Thus, bankers will be forced by capital owners not to continue late projects but to restructure them. But if there is no late project continued in the economy at an interest rate above $\tilde{r}$ there is no demand for liquidity at all.

If the interest rate meets exactly the threshold level $\tilde{r}$ capital owners are indifferent between restructuring and continuing late projects, so the demand for liquidity - the fraction of continued late projects - is undetermined in that case.

Altogether, the aggregate liquidity demand in the economy can be summarized by:

$$
L^{D}= \begin{cases}0 & r>\tilde{r} \\ {\left[0 ;(1-\bar{\alpha}) \frac{\gamma \cdot C}{(1+k) \cdot \hat{r}}\right]} & r=\tilde{r} \\ (1-\bar{\alpha}) \frac{\gamma \cdot C}{(1+k) \cdot r} & \hat{r}<r<\tilde{r} \\ (2-\bar{\alpha}-\underline{\alpha}) \frac{\gamma \cdot C}{(1+k) \cdot r} & r \leq \hat{r}\end{cases}
$$

Obviously, given this aggregate liquidity demand three qualitatively very different equilibria occur depending on the aggregate liquidity supply, which is given by the overall fraction of early projects in the economy.

Proposition 2 Depending on the aggregate fraction of late projects three types of $f_{-}$ nancial crises may emerge. 1) Slight liquidity crises, in which no bank collapses, 2) moderate liquidity crises, in which only weak banks are subject to a run and 3) severe liquidity squeezes, which also destabilize stronger banks.

Given that the overall fraction of late projects is rather limited, a slight liquidity crises occurs. This case is depicted in figure 1. Trying to attract new funds from the early entrepreneurs against the required mixture of deposits and capital banks bid up the interest rate only slightly to

$$
r^{*}=\frac{2-\bar{\alpha}-\underline{\alpha}}{\bar{\alpha}+\underline{\alpha}} \cdot \frac{\gamma}{1-\gamma} \cdot \frac{1}{1+k}
$$

But this only reduces the rents of the bank manager and the return of capital owners. It does not destabilize any bank in the economy.

Obviously, the interest rate in slight liquidity crises is the higher the larger the aggregate fraction of late projects relative to the fraction of early projects and the

\footnotetext{
${ }^{17}$ Note that we assumed $\tilde{r}$ always being below the interest rate level at which the strong bank cannot raise enough liquidity to repay deposits: $\hat{r}<\tilde{r}<\hat{\hat{r}}$.
} 


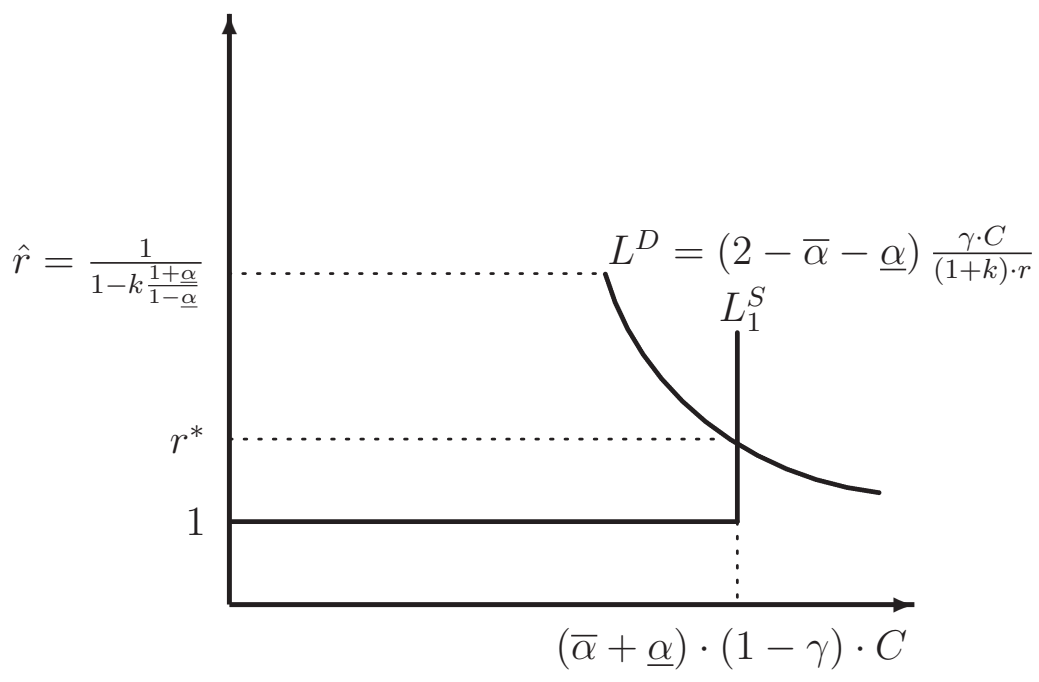

Figure 1: Equilibrium in a slight liquidity crisis

higher the relation of pledgable to non-pledgable income of finished projects, since both determine the relative scarcity of liquidity in $t_{1}$. Moreover, the interest rate is higher if the capital requirements are smaller, since capital requirements increase the rents of the banker and thereby reduce the returns of late project that can be promised to new depositors and capital owners in $t_{1}$.

However, if the "cash in the market"-constraint is more restrictive, i.e. the aggregate fraction of early projects smaller, the economy ends up in a moderate liquidity crises, in which part of the banking sector collapses. In that case, which is shown in figure 2 , the lack of liquidity causes the equilibrium interest rate to climb up to

$$
r^{* *}=\frac{1-\bar{\alpha}}{\bar{\alpha}+\underline{\alpha}} \cdot \frac{\gamma}{1-\gamma} \cdot \frac{1}{1+k}
$$

At this level the liquidity inflow at weak banks is insufficient to meet the repayment to depositors. Therefore, the banks with the stronger liquidity needs will fail, whereas the stronger banks, which are less dependent on the liquidity inflow from transaction in the $t_{1}$-financial market will not be destabilized by the liquidity squeeze and will continue all late projects. As the weak banks fail their depositors seize the late projects and restructure them. Since weak banks do not demand liquidity in the financial market at this interest rate levels, the equilibrium interest rate in a moderate liquidity crises only depends on the relation 1) of late projects at strong banks to the overall fraction on early projects, 2) of pledgable to non-pledgable income of finished projects and 3) of returns bank can pledge to new depositors and capital owners to her total return.

So roughly spoken, in a moderate liquidity crises only part of the banking sector 


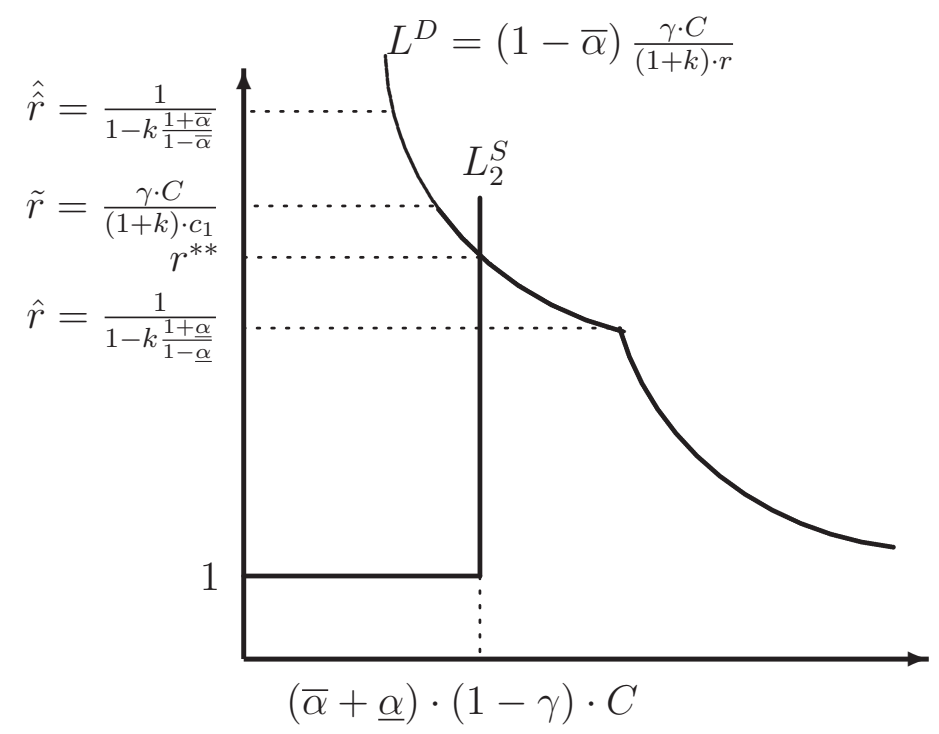

Figure 2: Equilibrium in a moderate liquidity crisis

that is subject to a more or less idiosyncratic adverse liquidity shock will collapse. The other part of the banking sector that does not face a severe idiosyncratic liquidity shock, because only a limited fraction of its projects turns out to be late, can finish all projects.

In contrast, if the aggregate fraction of late projects is even higher the economy ends up in a severe liquidity crisis. In this case the equilibrium interest rate will reach its upper bound

$$
r^{* * *}=\tilde{r}
$$

Obviously, at this interest rate level weak banks collapse. But what differentiates a moderate from a severe liquidity crisis is that in the latter even strong banks have to restructure part of their late projects. At the equilibrium interest rate $\tilde{r}$ capital owners are indifferent between restructuring and continuing late projects. However, the available liquidity is insufficient to repay all depositors. Therefore, the bank manager, who only receives a rent if projects are finished, will restructure just enough late projects to produce sufficient liquidity to prevent a run. The fraction of late projects that can be continued in a severe liquidity crises is given in equilibrium by

$$
\mu^{* * *}=\frac{\bar{\alpha}+\underline{\alpha}}{1-\bar{\alpha}} \cdot \frac{(1-\gamma)}{\gamma} \cdot \frac{(1-k) \cdot \tilde{r}}{1}=\frac{\bar{\alpha}+\underline{\alpha}}{1-\bar{\alpha}} \cdot \frac{(1-\gamma)}{\gamma} \cdot \frac{\gamma \cdot C}{c_{1}}
$$

Apparently, this fraction will be higher 1) the larger the aggregate fraction of early 


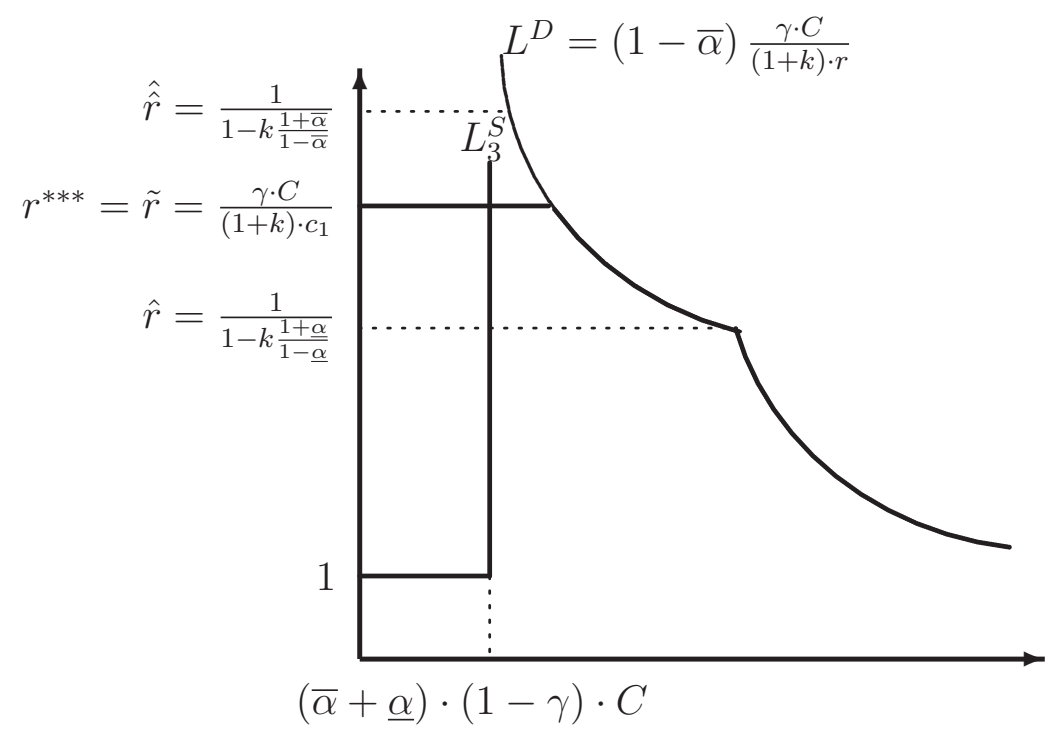

Figure 3: Equilibrium in a severe liquidity crisis

projects relative to the fraction of late projects at strong banks, 2) the higher the non-pledgable returns of entrepreneurs in relation to the pledgable returns going to the banks and 3) the smaller the present value of the fraction of the banks' returns that can credibly be promised to new capital owners and depositors at the given interest rate $\tilde{r}$. Inserting the equilibrium value for $\tilde{r}$ into the last expression shows that this is just the relation between the pledgable return of late projects if continued to the return of these projects if restructured (see equation (11)). Consequently, if continuing late projects gives a higher return to banks relative to restructuring, a higher fraction of late projects will be finished even in a severe liquidity shortage.

To sum up, in a severe liquidity shortage it is not enough that weak banks fail and therefore stop demanding liquidity. If the aggregate fraction of late projects is too high, even those banks that have financed a comparatively small fraction of projects that turn out to be late will not be able to raise enough liquidity at the financial market. However, these liquidity rationed banks do not collapse, but they will have to restructure late projects to raise sufficient liquidity to repay deposits.

Having described the equilibrium in the financial market it is straightforward to see which impact the particular type of the financial system has on the equilibrium. Obviously, the higher fraction of pledgable income $(\gamma)$ in bank-dominated financial systems shifts the entire liquidity demand to the upper right. Because the higher the pledgable income the higher the present value of late projects and the more aggressive banks can bid for funds in $t_{1}$ in slight and moderate liquidity crises. In severe liquidity 
crises the higher return on late projects makes capital owners more willing to accept a continuation of late projects even for higher interest rates. On the supply side a higher fraction of pledgable income reduces the return of early entrepreneurs, thereby lowering the liquidity supply in the economy. All these effects of a higher fraction of pledgable returns point in same direction: Fluctuations of the interest rate in case of a financial crisis are higher in bank-dominated financial systems than in market-oriented financial systems. This is also reflected in the respective equations of the equilibrium interest rate (see equations (8), (9) and (10))

A lower return on restructured projects $\left(c_{1}\right)$, which we also characterized as being typical for a bank-dominated financial system only influences the equilibrium interest rate in severe liquidity crises. The lower the returns from restructuring late projects the higher the interest rate up to which capital owners will accept a continuation of late projects of the bank manager. Thus, as can also be seen in equation (10), the interest rate fluctuations in severe liquidity crises also increase with a lower $c_{1}$ and are therefore higher in bank-dominated financial systems.

It is interesting to note, that also the threshold level for the different financial crises with respect to a given liquidity supply depends on the type of the financial system. Inserting $\tilde{r}$ into the liquidity demand one can derive the threshold level for aggregate liquidity supply between moderate and severe liquidity crises. This shows that if the aggregate liquidity supply falls short of $(1-\bar{\alpha}) \cdot c_{1}$ the economy ends up in a severe crisis. While this threshold level obviously is not influenced by the fraction of pledgable returns, it rises the higher the returns on restructured projects. Thus, in marketoriented financial systems, in which $c_{1}$ is higher, the economy ends up more often in a severe liquidity crisis, while in bank-dominated financial systems given a certain level of aggregate liquidity supply moderate liquidity crises are more likely. Similarly, the threshold level between slight and moderate liquidity crises can be derived by inserting $\hat{r}$ into the liquidity demand function showing that in bank-dominated financial systems characterized by a high $\gamma$ it is more likely to be in a moderate than in a slight liquidity crisis.

Proposition 3 In bank-dominated financial systems interest rate fluctuations are higher during financial crises than in market-oriented financial systems. Moderate liquidity crises are more likely in bank-dominated financial systems, while in market-oriented financial systems severe but also slight liquidity crises are more likely to occur. 


\section{Optimal LOLR-policy}

Restructuring late projects is always welfare reducing in this economy. If the interest rate is below $\tilde{r}$ this is most obvious, since in that case the net present value of the pledgable income from late projects that can credibly be promised to capital owners and depositors of the bank is higher than the returns generated if the projects are restructured.

$$
c_{1}<\frac{\gamma \cdot C}{(1+k) \cdot r} \quad \text { for } \quad r<\frac{\gamma \cdot C}{(1+k) \cdot c_{1}}
$$

However, even in a severe liquidity crisis, where the equilibrium interest rate reaches $\tilde{r}$ and the present value of the pledgable returns of continued late projects that can be credibly promised to outside financiers of the bank is therefore equal to the return of restructured late projects, it would still be strictly welfare improving to finish all projects. If late projects are continued entrepreneurs as well as bankers will earn a rent, while they both get nothing if projects are restructured. Since both rents are not pledgable they are never taken into account by capital owners of banks, when they decide to force the bankers to restructure late projects.

But besides the fact that parts of the returns a finished investment project generates can not be passed on by entrepreneurs and bank manager, which distorts the decision of bank owners to continue late projects, what contributes to the inefficient termination of late project is the bank's refinancing through deposits. What is in general the advantage of demand deposits - the threat of a coordination failure among depositors that allows bankers to credibly commit to repay - turns out to be a serious drawback in a liquidity crises particularly for weak banks. Banks are not able to bargain on the repayment of deposits in a crises situation to finish late projects.

A LOLR can provide banks with additional liquidity. To keep the analysis as simple as possible, we assume that the LOLR can raise the liquidity by taxing $t_{1}$ consumption. This can be interpreted as a shortcut for an inflation tax: The central bank as the LOLR increases the currency in circulation by providing additional means of payments to the banks to enable them to settle their nominal obligations. Since this increases the money supply without changing the contemporaneous provision of goods, it simply reduces the real value of money in terms of $t_{1}$-consumption goods. It therefore resembles a taxation of any $t_{1}$-consumption in the economy. ${ }^{18}$

However, the provision of liquidity by the LOLR is associated with a cost. An inflation tax just like any other tax (apart from per capita taxes) brings about ineffi-

\footnotetext{
${ }^{18}$ For a more detailed discussion of this argument see Allen and Gale (1998).
} 
ciencies in the economy that cause welfare losses. For simplicity we take these welfare losses $(W L)$ as an exogenous cost, that increases proportional with the volume of the liquidity assistance $(L A): W L=\beta \cdot L A$.

There are two distinct policies the LOLR can follow in providing the liquidity to the banking sector in a crisis. The first option, which captures the basic features of Bagehot's suggestions, is to supply liquidity to the market by buying financial assets, i.e. bank equity or deposits. In doing so the LOLR can stabilize the interest rate and prevent the banks from restructuring late projects. The second option, which reflects a more discrete policy, is to provide liquidity assistance to individual banks. Applying this policy the LOLR can supply liquidity at different terms to different banks.

In a slight liquidity crisis there is no need for a LOLR-intervention. All late projects are continued in spite of the liquidity shortage. The interest rate increase due to the slight liquidity squeeze only raises the consumption of early entrepreneurs at the expense of bank managers and bank capital owners. Therefore, a slight liquidity crisis only causes a reallocation of resources, that does not bring about any inefficiencies.

Proposition 4 In a slight liquidity crisis there is no need for a lender of last resort, since all late projects are continued anyway.

In a moderate liquidity crisis weak banks are threatened by a run in which depositors would seize the assets and restructure the late projects. Therefore, a liquidity assistance to prevent this could be beneficial.

If the LOLR decided to supply the weak banks with the funds to repay the deposits through an individual assistance $(I A)$, the amount of liquidity the LOLR has to provide is given by deposits less the liquidity available to the bank from the returns on early projects:

$$
L A_{m}^{I A}=D-\underline{\alpha} \cdot \gamma \cdot C
$$

The LOLR offers the liquidity assistance at the interest rate $\hat{r}$ against the future income of late projects that can be promised to outside financiers of the bank. So in $t_{1}$ there is just enough liquidity available to the bank to repay depositors. Therefore, the LOLR-assistance enables depositors to collect the full value of their deposits $(D)$ from late projects not just the return generated by restructuring $\left(c_{1}\right)$. Using the LOLR assistance even bank managers and bank capital owners gain since they can at least realize their rents from late projects $\left(\frac{2 \cdot k \cdot \gamma \cdot C}{1+k}\right)$. However, since these rents are realized in $t_{2}$ they have to be discounted with the rather high discount factor $\rho$ of bank managers 
and capital owners. ${ }^{19}$ In addition, the LOLR-assistance enabling the continuation of late projects also preserves the rents of late entrepreneurs. In sum, an individual liquidity assistance in a moderate liquidity crisis can generate welfare gains that amount to:

$$
W G_{m}^{I A}=(1-\underline{\alpha})\left[D-c_{1}+(1-\gamma) C+\frac{2 k}{1+k} \cdot \frac{\gamma C}{\rho}\right]-\beta[D-\underline{\alpha} \gamma C]
$$

If the LOLR uses market interventions to prevent inefficient restructuring of late projects in a moderate liquidity crisis he has to provide additional liquidity to the market up to the point where the interest rate is reduced to $\hat{r}$. At this level weak banks get just enough liquidity against the future pledgable returns of late projects to repay deposits. However, the additional liquidity the LOLR has to provide in that case is larger than if he uses an individual liquidity assistance. In addition to the liquidity needed at weak banks to repay depositors, the LOLR also has to meet the increase in liquidity demand of strong banks due to the interest rate reduction. Therefore, the overall liquidity supply by the LOLR using market intervention $(M I)$ amounts to:

$$
L A_{m}^{M I}=L A_{m}^{I A}+(1-\bar{\alpha}) \cdot\left[\frac{\gamma \cdot C}{(1+k) \cdot \hat{r}}-\frac{\gamma \cdot C}{(1+k) \cdot r^{* *}}\right]
$$

However, there are no welfare gains associated with the increased liquidity provision. The additional funds available to strong banks in $t_{1}$ only increase the consumption of bank managers and capital owners at the expense of the consumption of early entrepreneurs. This reallocation is neutral in terms of the overall welfare.

Therefore, the larger volume of liquidity provided in a market intervention does not bring about any benefits but causes additional costs. Thus a market intervention is always inferior in a moderate liquidity crises. The inefficiency of a market intervention is the higher the bigger the costs of the waste of liquidity. Inserting $\hat{r}$ and $r^{* *}$ into (14) the welfare losses from using market interventions in moderate liquidity crises are given by:

$$
W G_{m}^{I A}-W G_{m}^{M I}=\beta(1-\bar{\alpha})\left[\frac{(1-\underline{\alpha})-k(1+\underline{\alpha})}{(1-\underline{\alpha})} \cdot \frac{\gamma C}{(1+k)}-\frac{(\bar{\alpha}+\underline{\alpha})(1-\gamma) C}{(1-\bar{\alpha})}\right]
$$

Obviously, the inefficiency of a market intervention are more severe:

1. the larger the fraction of late projects at strong banks because

a) on the one hand this increases the additional liquidity demand of strong banks

\footnotetext{
${ }^{19}$ Remember that we assumed a discount rate for these agents that always exceeds the equilibrium interest rate. Therefore: $\rho>\tilde{r}$.
} 
and

b) on the other hand this reduces the supplied liquidity by early entrepreneurs in the economy, thereby increasing the liquidity that has to be supplied additionally to strong banks,

2. the larger the fraction of late projects at weak banks, because

a) on the one hand this reduces the liquidity supplied by early entrepreneurs, too, and

b) on the other hand this reduces the threshold level to which the LOLR has to bring down the interest rate to prevent a run on these banks,

3. the smaller the capital requirements, which is also mainly due to the reduction of liquidity demand by raising capital requirements and

4. the lower the fraction of non-pledgable income (the higher the pledgable return on late projects), also because a higher pledgable return increases additional liquidity demand of strong banks.

Consequently, in bank-dominated financial systems, which are particularly characterized by comparatively high levels of pledgable income, the inefficiencies of market interventions are more severe, whereas they are relatively limited in market-oriented systems.

Proposition 5 If a LOLR-intervention is beneficial at all in a moderate liquidity shortages an individual liquidity assistance is always preferable over a market-intervention. However, the efficiency loss of a market intervention is higher in bank-dominated financial systems.

In a severe liquidity crisis not only late projects at weak banks but also some of the delayed projects at strong banks would be restructured without an additional liquidity supply by a LOLR.

Applying individual liquidity assistance in a severe liquidity squeeze, the LOLR would have to supply to weak banks the same amount of liquidity as in moderate crises. In order to prevent the inefficient restructuring of late projects at weak banks the LOLR has to provide the additional liquidity that weak banks need to repay depositors at the threshold level $\hat{r}$. But in addition to prevent the inefficient restructuring at strong banks the LOLR has to supply them with the funds needed to finish their late projects, too. However, at strong banks it is not a potential run that could bring about the restructuring of late projects. At these banks it is the capital owners that do not 
allow the manager to pay higher interest rates than $\tilde{r}$ on funds allowing to continue late projects. Bank managers can use only the liquidity they get at $\tilde{r}$, to finish late projects, while they have to restructure the remaining delayed projects. Therefore, the LOLR simply has to supply the additional liquidity that strong banks need to continue all late projects at $\tilde{r}$. Thus, given the fraction of restructured late projects at strong banks without a LOLR-intervention $\left(1-\mu^{* * *}\right)$ the overall liquidity the LOLR has to provide to the banking system amounts to:

$$
L A_{s}^{I A}=D-\underline{\alpha} \gamma C+(1-\bar{\alpha})\left(1-\mu^{* * *}\right) \frac{\gamma C}{(1+k) \tilde{r}}
$$

Besides the welfare gains due to preventing the restructuring at weak banks in a severe crisis the LOLR-policy increases welfare by enabling strong banks to continue their late projects, too. However, since at strong banks depositors are repayed anyway, only bank managers, capital owners and late entrepreneurs benefit from the LOLR intervention, since their rents are preserved. Thus inserting the equilibrium values of $\mu^{* * *}$ and $\tilde{r}$ in a severe crisis overall welfare gains from an individual liquidity assistance are given by:

$$
\begin{aligned}
W G_{s}^{I A} & =W G_{m}^{I A}+(1-\mu)\left[(1-\gamma) C+\frac{2 k}{1+k} \frac{\gamma C}{\rho}\right] \\
& -\beta\left((1-\bar{\alpha}) c_{1}+(\bar{\alpha}+\underline{\alpha})(1-\gamma) C\right)
\end{aligned}
$$

In contrast, if the LOLR pursues a market intervention he has to provide enough liquidity to bring down the interest rate to $\hat{r}$, just like in a moderate liquidity squeeze. But again in order to do so, it is not sufficient to supply the same amount of liquidity to the market. At $\hat{r}$ strong banks do not just demand the liquidity needed to finish all late projects. Since the present value of their late projects is higher at $\hat{r}$ than at $\tilde{r}$ the additional liquidity they demand is given by:

$$
L A_{s}^{M I}-L A_{s}^{I A}=(1-\bar{\alpha})\left[\frac{\gamma C}{(1+k) \hat{r}}-\frac{\gamma C}{\left((1+k) r^{* * *}\right.}\right]
$$

But this additional liquidity provision again only brings about a reallocation of consumption between the bank managers and capital owners on the one hand and early entrepreneurs on the other. Thus, there are no overall welfare gains associated with this additional liquidity supply, only extra costs to raise these additional fund. Consequently, compared to an individual liquidity assistance market interventions are also inefficient in severe liquidity crises. Inserting $\hat{r}$ and $\tilde{r}$ into (19) the welfare gains from using an individual liquidity assistance instead of a market intervention as the LOLR-policy in a severe liquidity crises are given by: 


$$
W G_{s}^{I A}-W G_{s}^{M I}=\beta(1-\bar{\alpha})\left[\frac{\gamma C}{(1+k)} \frac{(1-\underline{\alpha})-k(1+\underline{\alpha})}{(1-\underline{\alpha})}-c_{1}\right]
$$

Obviously, applying individual liquidity assistance as the LOLR-policy is the more preferable in severe liquidity crises:

1. the larger the fraction of late projects at strong banks, because this raises the inefficient additional liquidity demand of strong banks,

2. the larger the fraction of late projects at weak banks, because an increase in the fraction of late projects at weak banks reduces the threshold level to which the LOLR has to bring down the interest rate to prevent a run on these banks,

3. the smaller the capital requirements, which is also mainly due to the reduction of liquidity demand by increasing capital requirements,

4. the higher the pledgable return on late projects, also because this increases additional liquidity demand of strong banks and and

5. the lower the return on restructured projects, since the lower $c_{1}$ the higher the difference between the interest rate in a market intervention $\hat{r}$ and the highest sustainable interest rate for strong banks $\tilde{r}$ and therefore the higher the additional (wasted) liquidity provision to strong banks in a market intervention.

Proposition 6 In a severe liquidity crisis an individual liquidity assistance is always preferable over a market-intervention, too. Again, the efficiency loss of a market intervention is higher in bank-dominated financial systems than in a market-based financial system.

To sum up, in all kinds of liquidity crises in which a LOLR-intervention is beneficial an individual liquidity assistance is strictly preferable. However, the welfare gains of an individual liquidity assistance compared to a market intervention vary with the particular parameter setting of the respective economy. Most interestingly, an individual liquidity assistance is in general more preferable the more the parametrization of the economy resembles a bank-dominated financial system. For instance, in both moderate as well as severe liquidity crises a high relation of pledgable to non pledgable income in financial relations between firms and banks (a higher $\gamma$ ), which is due to the relationship lending most characteristic for bank-dominated financial systems, makes an individual liquidity assistance more preferable. Moreover, relatively low returns from restructured projects $\left(c_{1}\right)$, which is also typical for bank-dominated financial system 
compared to market oriented financial systems, make an individual assistance more beneficial, too.

So far we did not take into account the different informational requirements of the LOLR-policies. However, it is obvious that an individual liquidity assistance requires much more information to be effective than a market intervention.

To pursue an individual liquidity assistance the LOLR has to collect precise information about the liquidity needs of every single bank. ${ }^{20}$ Besides the administrative costs, this takes time and may cause an inefficient delay of the LOLR-intervention. This is particularly true, since banks do not have an incentive to honestly report their liquidity needs to the LOLR. By overstating the fraction of late projects bank managers could increase the individual liquidity assistance and at the same time reduce the interest rate the LOLR demands on the provided liquidity. Both increases their rents.

In contrast, if the LOLR applies market interventions, the LOLR only has to keep the interest rate in the money market at the threshold level $\hat{r}$. Given that the lower bound $(1-\underline{\alpha})$ of the distribution of the fraction of late project is public information, there is no information on individual banks required by the LOLR.

In order to take these considerations into account but keep the analysis tractable we assume that there are some fixed informational costs associated with a policy of individual liquidity assistance.

So obviously, given these additional costs a policy of individual liquidity assistance is only preferable if the welfare gains of this LOLR-policy outweighs these costs. But as we have already argued the gains of an individual liquidity assistance differ with respect to the financial system under consideration. Thus, in a bank-dominated financial system in which the efficiency gains of an individual liquidity assistance are relatively large in moderate as well as in severe liquidity crises it is rather likely that a LOLR prefers to bear the additional information costs in order to be able to pursue this LOLR-policy. In contrast, in market-oriented financial systems, where the drawback of market interventions is in both types of financial crises less severe, the LOLR may decide to save the costs of acquiring the required information for an individual liquidity assistance and use market interventions to provide the banking system with additional liquidity.

Proposition 7 Taking into account, that there are more cost intense information requirements associated with an individual liquidity assistance, a LOLR-policy based on

\footnotetext{
${ }^{20}$ We assume that the LOLR cannot observe the region the bank is located in. Thus, the regions should not be taken literally but can be interpreted as sectors of the economy which are inflicted in different for outsiders not easily observable ways by the macroeconomic shock.
} 
individual liquidity assistance may be preferable in bank-based financial system but not in market-oriented financial systems.

\section{Conclusions}

In this paper on liquidity crises and lender of last resort policies we can distinguish between three different types of crisis situations. In a slight liquidity crisis there is no need for a lender of last resort. No banks are subject to a run, the only thing we observe is a slight increase of interest rates. In contrast, a moderate liquidity crisis is characterized by runs on weak banks. Depositors seize assets and late projects will be restructured. Finally, in a severe liquidity crisis not only runs on weak banks can be observed but also strong banks will be liquidity rationed and have to partially restructure their late projects. Accordingly, in a moderate and in a severe liquidity crisis the intervention of a lender of last resort may be preferable to prevent runs from occurring.

However, from our main results we can draw a connection between financial system configurations and the optimal lender of last resort policy, i.e. a market intervention following Bagehots' rules and lending liquidity freely at penalty rates, or an individual liquidity assistance provided discretionary by the lender of last resort.

In a moderate as well as in a severe liquidity crisis individual liquidity assistance guarantees a more efficient allocation of the provided liquidity. However, in both crisis situations the welfare losses due to the inefficient waste of liquidity are higher in bankdominated financial systems than in market-oriented financial systems. Thus, taking into account the more costly informational requirements of a lender of last resort that follows a policy of an individual liquidity assistance it may follow that the information costs outweigh the efficiency gain from a individual liquidity assistance in a marketoriented but not in a bank-oriented financial system.

Presumably, this argument in favor of a market intervention in market-oriented financial systems can further be strengthened: By incorporating into the analysis that a market intervention proportionally wastes more liquidity in the moderate than in the severe liquidity crises, we get lower efficiency loss from market intervention in a severe liquidity crisis if the informational costs of the LOLR increase with the amount of liquidity provided on an individual basis. Having in mind that, as we showed in Proposition 3, under reasonable assumption a market-oriented system is more often in a severe than in a moderate liquidity crisis, this also implies lower efficiency losses of a market intervention in a market-oriented system. 
Of course, there are important qualifications to this conclusion. Our model is incomplete in at least three aspects, which we want to analyze in future research. First of all we have to determine endogenously the decision of a lender of last resort to examine and inspect the banks who seek liquidity support in different financial systems. Secondly, in future work we want to elaborate on the ex ante decision of a bank about investing in projects and in storage technology. Thirdly and may be most important, our model is quiet about possible moral hazard behavior of banks induced by a lender of last resort. The only thing we can say for sure is that in our framework banks in bank-dominated systems acquire higher rents than banks in a market-oriented system, since the activity of the former are more firm-specific. Of course, these differences affect their behavior. In which direction the behavior will be influenced, that would be a very interesting and important topic of the LOLR policy analysis in the context of different financial systems. 


\section{References}

Allen, F., and D. Gale, 1998, "Optimal Financial Crises," Journal of Finance, 53, $1245-1283$.

Allen, F., and D. Gale, 2000, Comparing Financial Systems, MIT Press, Cambridge MA.

Allen, F., and D. Gale, 2001, "Comparpative Financial Systems: A Survey," Working Paper 01-15, Wharton Financial Institution Center.

Bagehot, W., 1873, Lombard Street, H.S. King, London.

Berlin, M., and L. Mester, 1998, "On the Profitability and Cost of Relationship Lending," Journal of Banking and Finance, 22, 873-897.

Diamond, D., and R. Rajan, 2000, "A Theory of Bank Capital," Journal of Finance, $55,2431-2465$.

Diamond, D., and R. Rajan, 2001, "Liquidity Risk, Liquidity Creation, and Financial Fragility: A Theory of Banking," Journal of Political Economy, 109, 287-327.

Diamond, D., and R. Rajan, 2002, "Liquidity Shortages and Banking Crises," Working Paper, University of Chicago.

Diamond, D. W., 1984, "Financial Intermediation and Delegated Monitoring," Review of Economic Studies, 51, 393-414.

Elsas, R., and J. Krahnen, 1998, "Is Relationship Lending Special? Evidence from Credit-File Data in Germany," Journal of Banking and Finance, 22, 1283-1316.

Fischer, S., 1999, "On the Need for an International Lender of Last Resort," Journal of Economic Perspectives, 13, 85-104.

Franks, J., and C. Mayer, 1995, "Ownership and Control," in H. Siebert (ed.), Trends in Business Organization: Do Participation and Cooperation Increase Competitiveness? . pp. 171-195, Mohr, Tbingen.

Freixas, X., B. Parigi, and J.-C. Rochet, forthcoming, "The Lender of Last Resort: A 21st Century Approach," Journal of European Economic Association.

Freixas, X. et al., November 1999, "Lender of Last Resort: A Review of Literature," Financial Stability Review, pp. 151-167. 
Giannini, C., 1999, "Enemy of None but a Common Friend of All? An International Perspectives on the Lender of Last Resort Function," Princeton Essays in International Finance.

Goodhart, C., 1995, The Central Bank and the Financial System, MIT Press, Cambridge, MA.

Goodhart, C., 1999, "Myths about the Lender of Last Resort," International Finance, 2, 339-360.

Gorton, G., and C. Kahn, 1992, "The Design of Bank Loan Contracts," Review of Financial Studies, 13, 331-364.

Hackethal, A., R. H. Schmidt, and M. Tyrell, 2002, "Convergence of Financial Systems in Europe," Schmalenbach Business Review, pp. 7-54.

Kahn, C., and J. Santos, 2001, "Allocating Bank Regulatory Powers: Lender of Last Resort, Deposit Insurance and Supervision," Working Paper 102, Bank for International Settlements.

Lindgren, C., G. G., and M. Saal, 1996, Bank Soundness and Macroeconomic Policy,, International Monetary Fund, Washington, D.C.

Rajan, R., 1992, "Insiders and Outsiders: The Choice between informed and arm's length debt," Journal of Finance, 47, 1113-1146.

Repullo, R., 2000, "Who Should Act as a Lender of Last Resort? An Incomplete Contract Model," Journal of Money, Credit and Banking, 32, 580-605.

Rochet, J.-C., and X. Vives, 2002, "Coordination Failures and the Lender of Last Resort Was Bagehot Right After All?," Working Paper, Universit de Toulouse and Universitat Autnoma de Barcelona.

Thornton, H., 1802, An Enquiry into the Nature and Effects of Paper Credit of Great Britain, Hatchard, London.

Tyrell, M., 2003, Kapitalmaerkte und Banken - Formen der Informationsverarbeitung als konstitutives Merkmal, Gabler, Wiesbaden. 


\section{The following Discussion Papers have been published since 2003:}

\section{Series 1: Studies of the Economic Research Centre}

January 2003 Testing mean-variance efficiency in CAPM with possibly non-gaussian errors: an exact simulation-based approach

January 2003 Finite-sample distributions of self-normalized sums

January 2003 The stock return-inflation puzzle and the asymmetric causality in stock returns, inflation and real activity

February 2003 Multiple equilibrium overnight rates in a dynamic interbank market game

February 2003 A comparison of dynamic panel data estimators: Monte Carlo evidence and an application to the investment function

March 2003 A Vectorautoregressive Investment Model (VIM) And Monetary Policy Transmission: Panel Evidence From German Firms

March 2003 The international integration of money markets in the central and east European accession countries: deviations from covered interest parity, capital controls and inefficiencies in the financial sector

March 2003 The international integration of foreign exchange markets in the central and east European accession countries: speculative efficiency, transaction costs and exchange rate premiums
Marie-Claude Beaul Jean-Marie Dufour Lynda Khalaf

Jeong-Ryeol Kim

Jeong-Ryeol Kim

Jens Tapking

Andreas Behr

Joerg Breitung

Robert S. Chirinko

Ulf von Kalckreuth

Sabine Herrmann

Axel Jochem

Sabine Herrmann

Axel Jochem 
Determinants of German FDI:

New Evidence from

Micro-Data

March 2003 On the Stability of

Different Financial Systems

April 2003 Determinants of German Foreign

Direct Investment in Latin American and

Asian Emerging Markets in the 1990s

June 2003 Active monetary policy, passive fiscal

policy and the value of public debt:

some further monetarist arithmetic

June 2003 Bidder Behavior in Repo Auctions

without Minimum Bid Rate:

Evidence from the Bundesbank

June 2003 Did the Bundesbank React to

Stock Price Movements?

152003 Money in a New-Keynesian model

estimated with German data

162003 Exact tests and confidence sets for the

tail coefficient of $\alpha$-stable distributions

172003 The Forecasting Performance of

German Stock Option Densities

182003 How wacky is the DAX? The changing

structure of German stock market volatility
Claudia Buch

Jörn Kleinert

Farid Toubal

Falko Fecht

Torsten Wezel

Leopold von Thadden

Tobias Linzert

Dieter Nautz

Jörg Breitung

Martin T. Bohl

Pierre L. Siklos

Thomas Werner

Jana Kremer

Giovanni Lombardo

Thomas Werner

Jean-Marie Dufour

Jeong-Ryeol Kurz-Kim

B R Craig, E Glatzer,

J Keller, M Scheicher

Jelena Stapf

Thomas Werner 
12004 Foreign Bank Entry into Emerging Economies:

An Empirical Assessment of the Determinants

and Risks Predicated on German FDI Data Torsten Wezel

22004 Does Co-Financing by Multilateral Development

Banks Increase "Risky" Direct Investment in

Emerging Markets? -

Evidence for German Banking FDI Torsten Wezel

32004 Policy Instrument Choice and Non-Coordinated Giovanni Lombardo Monetary Policy in Interdependent Economies Alan Sutherland

$42004 \quad$ Inflation Targeting Rules and Welfare

in an Asymmetric Currency Area Giovanni Lombardo

52004 FDI versus cross-border financial services: Claudia M. Buch

The globalisation of German banks Alexander Lipponer

$62004 \quad$ Clustering or competition? The foreign Claudia M. Buch

investment behaviour of German banks Alexander Lipponer

72004 PPP: a Disaggregated View Christoph Fischer

82004 A rental-equivalence index for owner-occupied Claudia Kurz housing in West Germany 1985 to 1998 Johannes Hoffmann

92004 The Inventory Cycle of the German Economy Thomas A. Knetsch

102004 Evaluating the German Inventory Cycle

Using Data from the Ifo Business Survey Thomas A. Knetsch

$112004 \quad$ Real-time data and business cycle analysis in Germany

Jörg Döpke

122004 Business Cycle Transmission from the US

to Germany - a Structural Factor Approach Sandra Eickmeier 
132004 Consumption Smoothing Across States and Time: George M.

International Insurance vs. Foreign Loans von Furstenberg

142004 Real-Time Estimation of the Output Gap

in Japan and its Usefulness for

Inflation Forecasting and Policymaking Koichiro Kamada

$152004 \quad$ Welfare Implications of the Design of a

Currency Union in Case of Member Countries

of Different Sizes and Output Persistence Rainer Frey

162004 On the decision to go public: Ekkehart Boehmer

Evidence from privately-held firms Alexander Ljungqvist

$172004 \quad$ Who do you trust while bubbles grow and blow?

A comparative analysis of the explanatory power

of accounting and patent information for the

Fred Ramb

market values of German firms

Markus Reitzig

182004 The Economic Impact of Venture Capital

Astrid Romain, Bruno

van Pottelsberghe

192004 The Determinants of Venture Capital:

Astrid Romain, Bruno

Additional Evidence

van Pottelsberghe

$202004 \quad$ Financial constraints for investors and the

speed of adaption: Are innovators special? Ulf von Kalckreuth

$212004 \quad$ How effective are automatic stabilisers?

Theory and results for Germany and other Michael Scharnagl

OECD countries

Karl-Heinz Tödter

2004 Asset Prices in Taylor Rules: Specification,

Pierre L. Siklos

Estimation, and Policy Implications for the

Thomas Werner

ECB

Martin T. Bohl 
$23 \quad 2004 \quad$ Financial Liberalization and Business

Cycles: The Experience of Countries in

Lúcio Vinhas

the Baltics and Central Eastern Europe

de Souza

242004 Towards a Joint Characterization of

Monetary Policy and the Dynamics of

the Term Structure of Interest Rates

Ralf Fendel

$252004 \quad$ How the Bundesbank really conducted

monetary policy: An analysis based on

real-time data

Christina Gerberding

Andreas Worms

Franz Seitz

262004 Real-time Data for Norway:

T. Bernhardsen, Ø. Eitrheim,

Challenges for Monetary Policy

A.S. Jore, Ø. Røisland

272004 Do Consumer Confidence Indexes Help

Forecast Consumer Spending in Real Time? Dean Croushore

282004 The use of real time information in

Maritta Paloviita

Phillips curve relationships for the euro area

David Mayes

292004 The reliability of Canadian output

Jean-Philippe Cayen

gap estimates

Simon van Norden

$30 \quad 2004 \quad$ Forecast quality and simple instrument rules -

a real-time data approach

Heinz Glück

Stefan P. Schleicher

$312004 \quad$ Measurement errors in GDP and

Peter Kugler

forward-looking monetary policy:

Thomas J. Jordan

The Swiss case

Carlos Lenz

Marcel R. Savioz

$32 \quad 2004 \quad$ Estimating Equilibrium Real Interest Rates

Todd E. Clark

in Real Time

Sharon Kozicki

332004 Interest rate reaction functions for the euro area Evidence from panel data analysis

Karsten Ruth 
342004 The Contribution of Rapid Financial

Development to Asymmetric Growth of

Manufacturing Industries:

George M.

Common Claims vs. Evidence for Poland

von Furstenberg

$352004 \quad$ Fiscal rules and monetary policy in a dynamic stochastic general equilibrium model

Jana Kremer

362004 Inflation and core money growth in the

Manfred J.M. Neumann

euro area

Claus Greiber

372004 Taylor rules for the euro area: the issue

Dieter Gerdesmeier

of real-time data

Barbara Roffia

$38 \quad 2004 \quad$ What do deficits tell us about debt?

Empirical evidence on creative accounting

Jürgen von Hagen

with fiscal rules in the EU

Guntram B. Wolff

$39 \quad 2004$

Optimal lender of last resort policy

Falko Fecht

in different financial systems

Marcel Tyrell 


\section{Series 2: Banking and Financial Supervision}

$12003 \quad$ Measuring the Discriminative Power

B. Engelmann,

of Rating Systems

E. Hayden, D. Tasche

22003 Credit Risk Factor Modeling and

A. Hamerle,

the Basel II IRB Approach

T. Liebig, D. Rösch

$12004 \quad$ Forecasting Credit Portfolio Risk

A. Hamerle,

T. Liebig, H. Scheule

22004 Systematic Risk in Recovery Rates -

An Empirical Analysis of US Corporate

Credit Exposures

\section{Klaus Düllmann \\ Monika Trapp}

32004 Does capital regulation matter for bank

Frank Heid

behaviour? Evidence for German savings

Daniel Porath

banks

Stéphanie Stolz

$42004 \quad$ German bank lending during

F. Heid, T. Nestmann, emerging market crises:

B. Weder di Mauro,

A bank level analysis

N. von Westernhagen

$52004 \quad$ How will Basel II affect bank lending to

T. Liebig, D. Porath, emerging markets? An analysis based on

B. Weder di Mauro,

German bank level data

M. Wedow 


\section{Visiting researcher at the Deutsche Bundesbank}

The Deutsche Bundesbank in Frankfurt is looking for a visiting researcher. Visitors should prepare a research project during their stay at the Bundesbank. Candidates must hold a $\mathrm{Ph} \mathrm{D}$ and be engaged in the field of either macroeconomics and monetary economics, financial markets or international economics. Proposed research projects should be from these fields. The visiting term will be from 3 to 6 months. Salary is commensurate with experience.

Applicants are requested to send a $\mathrm{CV}$, copies of recent papers, letters of reference and a proposal for a research project to:

Deutsche Bundesbank

Personalabteilung

Wilhelm-Epstein-Str. 14

D - 60431 Frankfurt

GERMANY 


